\title{
STRUKTUR PROTEOMIK VIRUS DENGUE DAN MANFAATNYA SEBAGAI TARGET ANTIVIRUS
}

\author{
Novia Rachmayanti
}

\begin{abstract}
Abstrak
Virus dengue (DENV) telah menyebabkan sekitar 50 juta kasus infeksi demam berdarah setiap tahunnya, akan tetapi hingga saat ini belum terdapat vaksin maupun antivirus yang mampu mencegah atau mengobati penyakit tersebut. Selama pengembangan vaksin dan antivirus, diperoleh berbagai informasi tentang struktur protein DENV yang dapat dimanfaatkan sebagai target obat. Makalah membahas tentang struktur proteomik pada DENV, yaitu glikoprotein pada envelope, NS3 protease, NS3 helikase, NS5 metiltransferase, dan NS5 RNA-dependent RNA polimerase.
\end{abstract}

Kata kunci: antivirus; struktur protein; virus dengue

\begin{abstract}
Dengue virus (DENV) has caused over 50 millions infection every year. However, to date neither vaccine nor medicine could be used to prevent or cure the illness. During researches in finding the vaccine or antiviral for DENV, information on DENV protein structure has been obtained which is potentially used as drug target. This paper disscuss DENV proteomic structure that consist of envelope glicoprotein, NS3 protease, NS3 helicase, NS5 methyl-transferase, and NS5 RNA-dependent RNA polymerase.
\end{abstract}

Keywords: antiviral; dengue virus; protein structure

Afiliasi Penulis : Program Studi Magister Ilmu Biomedik Fakultas Kedokteran Universitas Indonesia, Korespondensi: Novia Rachmayanti, Program Studi Magister IImu Biomedik Fakultas Kedokteran Universitas Indonesia, Jl. Salemba Raya No. 6 Jakarta Pusat, 10430, email: novia.rachmayanti@gmail.com Telp \HP: 089637056006 


\section{PENDAHULUAN}

Demam dengue (DD) dan demam berdarah dengue (DBD), yang disebabkan oleh virus dengue (DENV), telah menjadi masalah kesehatan global pada dekade terakhir. Infeksi DENV menyebabkan terjadinya permeabilitas saluran vaskular yang dimediasi oleh sitokin sel T yang menyerang sel terinfeksi. ${ }^{1}$ Manifestasi klinis akibat infeksi DENV dapat berupa gejala demam ringan, yang disertai dengan nyeri otot (mialgia), nyeri sendi (arthralgia), bintik kemerahan pada kulit (rash), penurunan jumlah sel leukosit, dan pembengkakan limpa. ${ }^{2}$ Demam berdarah dengue merupakan bentuk keparahan dari infeksi DENV yang ditandai dengan hilangnya plasma yang memicu gejala syok. DENV, yang terdiri atas 4 serotipe (DENV-1, DENV-2, DENV-3 \& DENV-4), mampu menimbulkan penyakit, mulai dari asimptomatik hingga DBD. ${ }^{1}$

DENV ditransmisikan ke manusia oleh vektor nyamuk Aedes aegypti atau Ae.albopictus, sehingga DENV endemik di negara tropis dan beberapa negara sub-tropis. ${ }^{1}$ Infeksi DENV telah menginfeksi lebih dari 100 juta jiwa dengan korban jiwa hingga 24.000 setiap tahunnya di dunia, ${ }^{3}$ dan lebih dari 50 juta orang yang terinfeksi DENV berasal dari Asia Tenggara, Pasifik Barat, Tengah dan Amerika Selatan. ${ }^{4}$ Namun demikian hingga saat ini, belum terdapat vaksin maupun antivirus yang efektif dalam mencegah dan mengobati infeksi DENV. ${ }^{5}$

Selama penelitian pengembangan vaksin dan antivirus, telah diperoleh berbagai informasi yang meningkatkan pemahaman tentang siklus hidup DENV, interaksi virus dengan sel inang, dan informasi tentang faktor-faktor penting transmisi virus. Analisis protein struktural dan non-struktural DENV bermanfaat untuk mengetahui lebih dalam mengenai mekanisme patogenesis DENV. ${ }^{6}$ Penelitian tersebut umumnya menitik-beratkan pada proses masuknya protein virus ke dalam sel, replikasi, perakitan, dan pematangan, sehingga diketahui tahapan penting perakitan virus yang dapat dijadikan sebagai target obat. ${ }^{7-10}$ Beberapa protein DENV yang memiliki potensi untuk dijadikan target obat ada-lah glikoprotein envelope (E), ${ }^{7}$ protein NS3 yang berfungsi sebagai helikase, ${ }^{8}$ dan protein NS5 yang memiliki dua fungsi sebagai metiltransferase ${ }^{9}$ serta $R N A$ dependent RNA polymerase. ${ }^{10}$

DENV adalah anggota dari keluarga Flaviviridae dan dikelompokkan dalam genus flavivirus dengan genom yang terdiri atas RNA positive-sense berukuran $\sim 11 \mathrm{~kb}$. RNA tersebut mengkode tiga protein struktural, yaitu protein kapsid (C), premembran/ membran (prM/M), dan $E$ yang akan membentuk komponen virion, serta tujuh protein non-struktural, yaitu NS1, NS2A/B, NS3, NS4A/B, NS5, yang terlibat dalam replikasi RNA virus (Gambar 1). ${ }^{11}$

Protein struktural DENV berperan penting dalam proses replikasi virus, mulai dari tahap penempelan virus ke sel target, perakitan, hingga pelepasan virus matang ke ekstrasel. Fungsi penting protein struktural dan non-struktural tersebut dapat dijadikan sebagai target penghambatan virus oleh obat antivirus. ${ }^{12}$

\section{METODE}

Penulisan artikel ini berdasarkan studi kepustakaan yang terkait dengan protein 
struktural dan non struktural virus Dengue sebagai target kerja obat anti virus.

\section{HASIL DAN PEMBAHASAN}

\section{Protein Kapsid (C)}

Protein C DENV ( 11 kDa) merupakan protein yang berinteraksi langsung dengan RNA virus membentuk kompleks nukleokapsid (NC). Bagian internal kapsid memiliki urutan asam amino hidrofobik sehingga memungkinkan kapsid untuk saling berasosiasi membentuk struktur membran. Protein C melipat membentuk dimer dan setiap monomernya terdiri atas empat alfaheliks. Bagian ujung $\mathrm{N}$ dan $\mathrm{C}$ protein tersebut memiliki asam amino bermuatan, sedangkan RNA virus akan berasosiasi dengan bagian ujung C. ${ }^{13}$

Proses dimerisasi protein $\mathrm{C}$ terjadi apabila terjadi interaksi antara protein $\mathrm{C}$ dengan asam nukleat. Apabila bagian ujung $C$ protein tersebut tidak berhasil berinteraksi dengan RNA virus, maka dimerisasi protein $\mathrm{C}$ gagal dilakukan dan struktur kapsid tidak akan terbentuk. Proses dimerisasi protein $\mathrm{C}$ berpotensi sebagai target antivirus. Penelitian in vitro untuk mengidentifikasi bahan yang dapat menghalangi dimerisasi protein $C$ atau interaksi antara protein C-RNA akan sangat bermanfaat. ${ }^{12}$

\section{Protein Envelope (E)}

Penempelan virus pada sel target dimediasi oleh protein $\mathrm{E}$, dan kemudian virus masuk ke sel melalui jalur receptormediated endocytosis. $\mathrm{pH}$ rendah pada kompartemen endosomal ( 5,8-6,0) memicu terjadinya fusi antara membran virus dengan membran sel inang, sehingga akan terjadi pelepasan nukleokapsid dan RNA virus ke sito- plasma. ${ }^{12} \mathrm{pH}$ lingkungan sel yang rendah akan menyebabkan terjadi perubahan konformasi protein $\mathrm{E}$ dari 90 homodimer pada $\mathrm{pH}$ netral menjadi 60 homotrimer. ${ }^{13}$

Protein $\mathrm{E}$ merupakan titik kontak pertama antara virus dan sel inang. Beberapa protein seluler dan molekul karbohidrat berfungsi sebagai faktor penempelan yang mememediasi masuknya virus, dan molekul-molekul tersebut diketahui berinteraksi dengan $\mathrm{E}$ protein. ${ }^{14}$ Faktor-faktor tersebut membantu penempelan virus pada permukaan sel inang dan meningkatkan akses ke reseptor seluler spesifik. Sayangnya, reseptor seluler spesifik untuk DENV belum diidentifikasi.

Protein E DENV memiliki tiga domain, yaitu DI, DII dan DIII. Pada $\mathrm{pH}$ rendah, fusion loop yang berada pada DII, yang sebelumnya tertutup DI dan DIII, menjadi terpapar/terekspos. Hal tersebut menyebabkan protein $\mathrm{E}$ trimer berpotensi untuk melakukan fusi dan menginfeksi sel target. Pemahaman tentang mekanisme pematangan dan fusi protein tersebut dapat dimanfaatkan sebagai daerah sasaran antivirus. Berdasarkan hal tersebut, terdapat tiga daerah pada protein virus yang mampu dihambat oleh antivirus, yaitu: $\beta-O G$ binding pocket, protein $\mathrm{E}$ pada virus matang, dan protein $\mathrm{E}$ pada bentuk homotrimer. ${ }^{12}$

\section{Protein NS3 Protease}

NS3 (618 residu asam amino) merupakan protein multifungsi yang berfungsi sebagai serin protease, RNA helikase, dan RTPase / NTPase. Residu 1-180 NS3 pada N-terminal merupakan domain serin protease yang berfungsi untuk memotong poliprotein DENV di beberapa situs. Enzim tersebut terdiri 
atas enam $\beta$-sheet yang membentuk dua $\beta$-barel dengan triad katalitik (His-51, Asp-75, dan Ser-135) terjepit di antara mereka. Aktivitas NS3 protease sangat tergantung pada keberadaan protein NS2B. Protein NS2B merupakan protein integral yang strukturnya sangat lestari pada flavivirus. ${ }^{15}$

Berdasarkan analisis struktur protein, residu 67-80 dari NS2B sangat penting untuk aktivitas protease NS3. Hal tersebut disebabkan karena NS2B membungkus bagian sekitar domain protease menyerupai struktur "sabuk" dan membentuk bagian integral pada situs protease aktif, sementara bagian inti NS2B (residu 67-80) berinteraksi dengan protease. Daerah hidrofobik NS2B diduga akan mengikat kompleks NS2B-NS3 pada membran RE. Bentuk tersebut memungkinkan situs aktif protease terletak dekat dengan domain poliprotein yang harus dipotong. Lokasi situs pemotongan NS3 memerlukan dua basa dengan motif (Arg/Lys)-Arg, masing-masing pada posisi P1 dan P2, serta asam amino (Gly) pada posisi P1'. 16

Pemrosesan poliprotein DENV merupakan tahap terpenting yang harus dilakukan virus sebelum replikasi RNA berlangsung (Gambar 1). ${ }^{11}$ Setelah RNA virus masuk ke sitoplasma, RNA akan ditranslasi menjadi poliprotein, kemudian protein tersebut ditransportasikan ke dalam RE. Translasi dan pasca-translasi RNA dilakukan oleh enzim serinprotease virus, yaitu NS2B-NS3, serta protease dari sel inang, yaitu signalase dan furin. Protease-protease tersebut memotong poliprotein menjadi tiga protein struktural dan tujuh protein nonstruktural dengan urutan: C-prM-E-NS1NS2A-NS2B-NS3-NS4A-NS4B-NS5.
Urutan sinyal poliprotein terletak di NS1; domain preM-E terletak pada lumen $R E$; protein $\mathrm{C}, \mathrm{NS} 3$, dan NS5 terlokalisasi di sitoplasma, sedangkan protein NS2A/B dan NS4A/B terletak sebagai protein transmembran. ${ }^{12}$ Kemampuan protein NS3 sebagai protease sangat diperlukan oleh virus untuk bereplikasi, oleh karena itu domain protease tersebut berpotensi besar menjadi sasaran antivirus.

\section{Protein NS3 Helikase}

NS3 helikase DENV (residu 180618) memiliki tujuh motif struktural yang menyerupai struktur superfamili 2 helikase. Helikase NS3 DENV memiliki tiga subdomain dengan urutan dan bentuk yang berbeda jika dibandingkan dengan helikase flavivirus lainnya. ${ }^{17}$ Subdomain I dan II, secara struktural mirip dengan domain pada virus hepatitis $\mathrm{C}$, yaitu memiliki lipatan pada subdomain III yang hanya terdapat pada flavivirus. Hal tersebut mengindikasikan bahwa secara umum mekanisme fungsional domain tersebut sama. Diduga lipatan tersebut adalah situs pengikatan protein. ${ }^{18}$

Subdomain I (residu 181-326) dan II (residu 327-481) terdiri atas enam untai $\beta$-sheet sejajar sentral, yang diapit oleh empat $\alpha$-heliks. Subdomain III (residu 482-618) memiliki kira-kira empat a-heliks sejajar yang dikelilingi oleh tiga $\alpha$-heliks pendek dan dua $\beta$-sheet antiparalel yang dapat terpapar pelarut. Berdasarkan struktur full-length NS3, domain helikase flavivirus memiliki struktur yang mirip dengan helikase DENV. Namun, aktivitas helikase dari protein NS3 full-length flavivirus meiliki aktivitas 30 kali lipat lebih tinggi daripada domain helikase DENV, hal tersebut menunjukkan bahwa domain protease dapat mempengaruhi aktivitas enzimatik 
helikase. Protease dan helikase dihubungkan oleh interdomain linker yang tingkat kelestariannya rendah antarflavivirus, akan tetapi berperan penting untuk asosiasi antara dua domain pada NS3 (luas permukaan yang tertutup antar-domain adalah 1380Å2 (dengan linker) dan $~ 380 \AA 2$ (tanpa linker). ${ }^{19}$

Domain helikase NS3 juga terlibat dalam interaksi dengan polimerase DENV, yaitu protein NS5. Residu domain helikase NS3 (W349) terbukti terlibat dalam perakitan virus yang menunjukkan bahwa NS3 memiliki fungsi tambahan dalam siklus hidup serta replikasi RNA virus. Protein NS3 juga diketahui terlibat dalam induksi apoptosis sel yang terinfeksi. ${ }^{11}$ Sama halnya dengan domain NS3 protease, domain NS3 helikase merupakan daerah yang berpotensi sebagai daerah penghambatan oleh antivirus.

\section{Protein NS5 metiltransferase (MTase)}

Protein NS5 merupakan protein terbesar (900 residu asam amino; $104 \mathrm{kDa})$ dan memiliki urutan asam amino paling lestari pada DENV (DENV 1-4 $67 \%$ identik). Hal tersebut dikarenakan fungsi penting protein tersebut, yaitu sebagai metiltransferase (MTase; residu 1-296) pada N-terminal, serta sebagai RNA-dependent RNA polymerase (RdRp; residu 320-900) pada C-terminal. ${ }^{20}$

Protein NS5 MTase merupakan salah satu protein virus yang banyak diteliti sebagai target antivirus. Untuk proses 5'-capping pada RNA virus, dibutuhkan empat macam aktivitas enzim, salah satunya MTase. Domain fungsional NS5 MTase berada pada bagian N-terminal protein NS5. Pada bagian tersebut, NS5 MTase akan memetilasi posisi N-7 pada cap guanine dan pada ribosa 2'-OH dari nukleotida yang pertama kali ditranskripsi, yaitu adenine ( $\left.\mathrm{m}^{7} \mathrm{GpppAm}\right)$. Mutasi pada residu asam amino yang penting untuk proses metilasi dapat menyebabkan kegagalan replikasi virus. Hal tersebut mengindikasikan bahwa protein NS5 MTase berperan penting dalam siklus replikasi virus. ${ }^{12}$

\section{Protein NS5 RNA-dependent RNA polymerase (RdRp)}

Struktur domain polimerase NS5 flavivirus diketahui mirip dengan molekul RdRp virus lainnya. NS5 RdRp memiliki mekanisme katalitik yang sama untuk penggabungan nukleotida, yaitu dengan memanfaatkan dua ion logam yang dikoordinasikan oleh suatu struktur lestrari residu asam aspartat (disebut juga sebagai motif GDD). Struktur RdRp berbeda dari polymerase DNAdependent RNA karena memiliki bentuk "finger tips" berbeda untuk membuat situs aktif sepenuhnya. ${ }^{21}$

Pada infeksi DENV, protein NS5 terlokalisasi terutama pada bagian inti sel. Namun, tidak semua RdRp NS5 flavivirus terletak pada inti sel. Alasan mengapa $\mathrm{RdRp}$ virus terlokalisasi pada inti, padahal peran utama enzim dalam siklus hidup virus seharusnya ada pada sitoplasma, hingga saat ini belum diketahui dan masih diteliti. Namun, diduga bahwa selain dari fungsi enzimatiknya, protein NS5 juga terlibat dalam interaksi virus-inang dan secara aktif berinteraksi dengan lingkungan inang. 22

RdRp merupakan salah satu kelas enzim yang paling menjanjikan untuk dijadikan sebagai target antivirus, karena manusia tidak memiliki / memer- 
lukan enzim tersebut. Aktivitas polimerase virus dapat dihambat menggunakan analog nukleosida atau non-nukleosida. Bahan non-nukleosida menghambat pada sisi alosterik enzim. Analog nukleosida harus terfosforilasi menjadi 5'trifosfat, sehingga obat berubah ke bentuk aktif yang dapat berikatan dengan situs aktif enzim dan menghambat aktivitasnya. $^{12}$

\section{Protein Non-Struktural Lainnya}

Sayangnya, belum terdapat informasi yang lengkap tentang struktur protein NS1, NS2A dan, NS4A/4B untuk DENV. Protein NS1 merupakan glikoprotein berukuran $45 \mathrm{kDa}$ yang ditranslokasi ke dalam lumen RE dan disekresikan dari sel. Proses translokasi dan sekresi tersebut berperan dalam fungsi replikasi RNA virus, serta untuk pertahanan virus dengan cara menghambat aktivasi komplemen. ${ }^{11}$

\section{Protein hidrofobik NS2A dan} NS4A/4B juga masih belum banyak diteliti. Protein NS2A ( 22kDa) merupakan bagian dari proses kompleks replikasi. Sebagai akibat dari pemotongan internal NS3-NS2B, maka terdapat dua bentuk, NS2A dan NS2Aa. Kedua bentuk protein tersebut diduga penting pada tahap produksi virus. NS4A (16kDa) dan NS4B (27kDa) adalah protein integral / transmembran. NS4A diduga dapat menginduksi perubahan membran yang penting dalam replikasi virus. NS4B berperan dalam membantu replikasi virus RNA melalui interaksi langsung dengan NS3. Protein NS4B juga diduga dapat memblokir transduksi sinyal IFN $\alpha / \beta$-diinduksi. Analisis struktural dari ketiga protein tersebut gagal karena seluruh protein memiliki beberapa segmen transmembran hidrofobik.
Namun, topologi membran NS4A dan NS4B telah diprediksi melalui analisis biokimia. ${ }^{11}$ Studi lebih lanjut tentang protein non-struktural tersebut diharapkan mampu menambah informasi yang berguna bagi pengembangan antivirus.

\section{SIMPULAN}

Penelitian saat ini telah memberikan informasi tentang fungsi struktural protein DENV yang sangat membantu pada pengembangan antivirus DENV. Walaupun informasi tersebut telah diperoleh, sifat multi-fungsional dari protein DENV masih memerlukan informasi tambahan untuk memahami bagaimana protein berinteraksi untuk bereplikasi secara aktif dalam proses perakitan virus. Penelitian paralel untuk identifikasi protein virus dan interaksi virus dengan sel inang sangat penting untuk mengetahui siklus hidup virus secara lengkap.

\section{DAFTAR RUJUKAN}

1. Gubler DJ. Dengue and dengue hemorrhagic fever. Clin Microbiol Rev 1998;11(3):480-96.

2. Kinney RM, Huang CY. Development of new vaccines against dengue fever and Japanese encephalitis. Intervirology 2001;44:176-96.

3. World Health Organization (WHO). Comprehensive guideline for prevention and control of dengue and dengue haemorrhagic fever. Revised and expanded edition. Regional office for South East Asia. 2011.

4. Kinney RM, Huang CYH. Development of new vaccination against dengue fever and Japanese encephalistis. Intervirology 2001; 44:176-97.

5. Rico-Hesse R. Dengue virus markers of virulence and patho-genecity. Future Virol 2009;4(6):581.

6. Morens DM, Fauci AS. Dengue and hemorrhagic fever: a potential threat to public health in the United States. Jama 2008;299:214-6. 
7. Perera R, Khaliq M, Kuhn RJ. Closing the door on flaviviruses: Entry as a target for antiviral drug design. Antiviral Res 2008. In press.

8. Lescar J, Dahai L, Xu T, et al. Towards the design of antiviral inhibitors against flaviviruses: the case for the multifunctional NS3 protein from Dengue virus as a target. J Antiviral 2008;80(2):94-101.

9. Dong HP, Ray D, Ren SP, et al. Distinct RNA elements confer specificity to flavivirus RNA cap methylation events. J Virol 2007;81:4412-21.

10. Malet $H$, Massé $N$, Selisko $B$, et al. The flavivirus polymerase as a target for drug discovery. Antiviral Res 2008;80(1):23-35

11. Perera R, Kuhn RJ. Structural proteomic of dengue virus. Curr Opin Microbiol 2009;11(4):377-96.

12. Sampath A, Padmanabhan R. Molecular targets for flavivirus drug discoveries. Antiviral Res 2009;81(1):6-15.

13. Stiasny K, Heinz FX. Flavivirus membrane fusion. J Gen Virol 2006;87:2755-66.

14. Navarro-Sanchez E, Altmeyer R, Amara A, et al. Dendritic-cell-specific ICAM3-grabbing non-integrin is essential for the productive infection of human dendritic cells by mosquito-cell-derived dengue viruses. EMBO Rep 2003;4:723-28.

15. Falgout $B$, Pethel $M$, Zhang YM, Lai CJ. Both nonstructural proteins NS2B anbd NS3 are required for the proteolytic processing of Dengue virus nonstructural proteins. J Virol 1991;65:2467-75.
16. Li L, Lok SM, Yu IM, et al. The flavivirus precursor membrane-envelope protein complex and its implication for maturation. Science 2008;319:1830-34.

17. Gorbalenya AE, Koonin EV. Helicase: Amino acid sequence-comparisons and structure-function relationships. Curr Opin Struct Biol 1993;34:419-29.

18. Yao N, Hesson T, Cable M, et al. Structure of the hepatitis $C$ virus RNA helicase domain. Nat Struct Biol 1997;4:463-67.

19. Wu J, Bera K, Kuhn RJ, Smith JL. Structure of the flavivirus helicase: implications for catalytic activity, protein interaction, and proteolytic processing. J Virol 2005;79:10277-86.

20. Elgoff MP, Benarroch D, Selisko B, Romette JL, Canard B. An RNA cap (nucleoside-2'O)-methyltransferase in the flavivirus RNA polymerase NS5: crystal structure and fuctional characterization. Embo $\mathrm{J}$ 2002;21:2757-68.

21. Ferrer-Orta C, Arias A, Escarmis C, Verdaguer N. A comparison of viral RNAdependent RNA polymerases. Curr Opin Struct Biol 2006;16:27-34.

22. Pryor MJ, Rawlinson SM, Butcher RE, et al. Nuclear localization of dengue virus nonstructural protein 5 through its importin alpha/beta recognized nuclear localization sequences is integral to viral infection. Traffic 2007;8:795-807. 